\title{
LIBURNIA AS A MANSION OF CENTRAL EUROPE: MEMOIRS AND LITERARY TESTIMONY BY IVANA BRLIĆ-MAŽURANIĆ
}

\author{
Vjekoslava Jurdana
}

\begin{abstract}
Liburnia is a geographic region along the eastern coast of Istria, bordered by Učka, Preluk and Plomin Bay. Its linguistic and cultural dimensions are strongly determined by its geological, geographical and political uniqueness. In the middle of the $19^{\text {th }}$ century, this area began to develop as an elite Central European tourist destination. Within the AustroHungarian Monarchy, Opatija was a well-known Liburnian winter and summer resort. Members of the royal families, composers and writers came to visit Opatija, including the famous Croatian writer Ivana Brlić-Mažuranić. Based on documents recently discovered in Ivana's correspondence, this paper documents and depicts her stays in Liburnia, which have not been researched and written about before. Moreover, the recent literature related to tourist and cultural history of Liburnia emphasizes numerous famous guests who visited this area, but fails to mention Ivana Brlić-Mažuranić. In addition to Ivana's correspondence, this paper analyses her portrayal of Liburnia based on her memoirs and lyrical prose. Her work is an expressive testimony of the development of the culture of travel of the $19^{\text {th }}$ century Central-European upper class. Ultimately, it is a valuable portrayal of Liburnia at the end of the $19^{\text {th }}$ and beginning of the $20^{\text {th }}$ centuries, which was the time of its intense tourist expansion.
\end{abstract}

Keywords: Liburnia, Central Europe, Ivana Brlić-Mažuranić, literary testimony, the culture of travel 


\section{INTRODUCTION}

Ivana Brlić-Mažuranić (Ogulin, 18 April 1874 - Zagreb, 21 September 1938) is a distinguished Croatian writer and the first female academician of the Yugoslav Academy of Sciences and Arts. She was born into the Mažuranić family from the Croatian Littoral, which, along with her famous grandfather Ivan, gave a number of other writers and philologists, such as Antun, Fran, Matija and Vladimir Mažuranić. From this celebrated family, Ivana Mažuranić married into the Brlić family of Slavonski Brod - an old family, likewise, important for Croatian culture. During her life, Ivana often came to the Croatian Littoral and wrote about her visits in her memoirs and essays. Moreover, Ivana Brlić-Mažuranić's stays in the Croatian Littoral are evidenced by her correspondence. All of these documents show her affection in describing the western cost of the Croatian Littoral, i.e. of the Kvarner, an area called Liburnia. In this work, first the chronology of Ivana's visits to Liburnia is (re)constructed, based on her memoirs and prose. The recently found documents from Ivana's correspondence are presented and analysed within this newly-created framework.

In these documents it is possible to recognize the specific features of the culture of everyday life of the upper middle class of Central Europe. This life, among other things, reveals the amenities of tourist travelling and vacations in special destinations as well as their healing effects both mentally and physically.

\section{LIBURNIA AS A MANSION OF CENTRAL EUROPE}

Liburnian history points to a social and cultural contingency, stratification, complexity. More precisely, we focus on the so-called Istrian Liburnia, a region bordered by Učka, Preluk and Plomin Bay. Its linguistic and cultural dimensions are strongly determined by its geological, geographical and political uniqueness.

This part of the Istrian peninsula, namely Liburnia, is (still today) scattered with picturesque places: Volosko, Opatija, Ičići, Ika, Lovran, Medveja, Mošćenička Draga, Brseč, Plomin. 
The central place is Opatija, whose name suggests that it was established around its core nucleus - the Benedictine Abbey of St. James (mentioned for the first time in 1438/39). In the 1880s, Opatija became a mansion for the members of the higher social strata. Lovran, along with Opatija, was also becoming more and more known as a health resort. A water supply network, power supply network and a tram line connecting Lovran with the Opatija railway station in Matulji were built. This was the time of the rise of the middle class, which, like the earlier aristocratic classes, needed to fulfil their free time and to conceive their leisure. In Central Europe, these classes, made up of landlords, families of senior clerks, bankers, doctors and traders, early retired officers, chronic patients, wealthier students, artists, were forced to 'survive' the grey and long winters. Opatija and its surroundings provided them with a shelter, offering a pleasant climate during wintertime. What is more, being connected by rail to major cities in Austria-Hungary, it was a relatively close destination. (Zakošek 2005: 35-36) By the beginning of the $20^{\text {th }}$ century, Liburnia and its main centre Opatija, had been established as a renowned holiday resort in the Austro-Hungarian Monarchy with dozens of sanatoriums and about thirty physicians. It was visited by members of the royal and imperial families, composers and writers.

During these idyllic, golden times, Liburnia was visited also by foreign writers. Among the foreigners (whatever this meant for Opatija and Liburnia), James Joyce came here (perhaps on a trip from Trieste or Pula where he lived for some time), Gabriele D’Annunzio, Anton Pavlovich Chekhov (he stayed at the Kvarner Hotel 1894: in his short story Ariadne Opatija was not exactly described with approval) Vladimir Nabokov (as a child he spent the summer of 1904 at Villa Neptun) and Ferencz Molnár (1903) (Muzur 2004), Stanisław Witkiewicz (1851-1915), the famous Polish painter, writer and author of the so called Zakopane Style of architecture, spent many years in Lovran, where he died in 1915. In addition, many travel writers spurred a lively interest in Liburnia in their travel books (Peršić, 2002: 16). ${ }^{[1]}$ However, in this entire constellation of writers, both

[1] Peter Radica, Abbazia, Wien, 1884.; Ludwig Salvator von Habsburg, Lose Blätter aus Abbazia, Wien,1886.; Heinrich Noe, Geleitbuch nach Süden auf den Karst nach Abbazia, München, 1889.; Heinrich Noe, Tagebuch aus Abbazia, Wien,1890.; Joseph Rabl,Curort and Seebad Abbazia, Wien, 1890.; Berbard Lesker, Eine Fahrt an die Adria, Stuttgart,1895.; Venturini Domenico, Sulla Riviera Liburnica, Fiume, 1897.; Eduard Seis, Sommer und Winterkurort Lovrana, Abbazia, 1910. 
domestic and foreign, in Liburnia, Ivana Brlić-Mažuranić is not mentioned at all. Let us now show the extent of our research on the presence of Ivana, both living and creating in the Liburnian area, especially in the two largest places: Opatija and Lovran. The material presented here comes from two archive sources: from Slavonski Brod (Archives of the Brlić Family Croatian Institute of History) and Rijeka (The Memorial Library and the Mažuranić-Brlić-Ružić Collection - Matilda Ružić Foundation).

Based on this material and the study of Ivana's memoirs, this paper singles out three of Ivana's descriptions of her encounters with Liburnia. These three descriptions are related to various periods of Ivana's life and are therefore somewhat different in their tone and style.

a) The first description revisits her youthful days, namely 1889, when Ivana was 15 years old and went on her first trip to the seaside.

b) The second description is from 1906, when Ivana, as a 32-yearold married woman and mother, spent her holidays in Opatija with her husband and son Ivan.

c) The third description dates back to 1913, when Ivana, now mature at the age of 39 , spent a summer in Lovran with her husband and daughter Nada.

\section{1889. PUTNE BILJEŠKE: ABBAZIA RAJ U KOM UVIEK PROLJEĆE VLADA (1889 TRAVEL NOTES: OPATIJA, A PARADISE OF EVERLASTING SPRING)}

Ivana Mažuranić, as a fifteen-year-old girl, noted impressions of her first trip to the sea in the records entitled Putne bilješke s puta iz Zagreba preko Slovenije i Rijeke u Novi od 13. 04.1889. - 15. 04. 1889. (Travel Notes from the journey from Zagreb via Slovenia and Rijeka to Novi dated 13 April 1889 - 15 April 1889) (Brlić-Mažuranić 2016, 23-39)

On that journey, Ivana would see the sea, the so much desired sea, for the first time. Within this framework, we are interested in her experience of Liburnia. On Thursday, $19^{\text {th }}$ April, they travelled to the Kvarner Bay by a steamer. Ivana wrote:

Bili smo u Opatiji. Ta ciela Opatija je prekrasan tropijski perivoj. 
Visoko kamelijsko grmlje puno najljepših crvenkamelijah pokazuju da je tu sad već vrlo blagi zrak. (Brlić-Mažuranić 2016, 35)

(We were in Opatija. The entire Opatija is a beautiful tropical park. The tall camellia shrubs with the most beautiful red camellia flowers show that the air is already very mild here.) (Brlić-Mažuranić 2016, 35)

And continues:

Podneblje nije toliko vruće ko ugodno, zrak tako rekuć mehak, more krotko, sve u najljepšem zelenilu ko posred ljeta. Vrlo je mnogo lovora po parku, a i drugih inozemnih divnih biljakah i stabalah. Mnogo ima villah a najveći je „Hotel Štefanija“. U hladovitih putih parka nije ti prehladno, na suncu ni ti prevruće, začudo je kako je sve ugodno i milo. Sve je tako čisto, tako uredno. Nu zato i nema naroda koj tu ne bi bio zastupan. Na brodu na kojem smo se vozili bilo je Hrvata, Njemaca, Madjara, Poljakah, Russah, i ako se nevaram, Englezah i Talijanah. Abbazzia je mali raj u kom se čini da uviek proljeće vlada. (BrlićMažuranić 2016, 35- 36)

The climate is not as hot but comfortable, the air is so mild, the sea is tame, all in the most beautiful greenery, as in the middle of summer. There are a lot of laurel trees in the park, and other foreign magnificent plants and trees. There are many villas and the largest is "Hotel Štefanija"[2]. In the shadows of the park one is not cold, nor is one hot in the sun, it is surprising that it is all so pleasant and dear. Everything is so clean, so near. But, there is no nation that is not be represented here. There were Croatians, Germans, Hungarians, Polish, Russians, and, if I am not wrong, English and Italians on the boat we were sailing on. Opatija is a small paradise of everlasting spring. (Brlić-Mažuranić 2016, 3536)

It is most obvious that in this first memoir of 1889, Ivana describes Opatija, as well as Liburnia, as a fairy-tale oasis of natural and human harmony, giving it almost unrealistic connotations of an enthusiastic adolescent romantic (de Canziani 2016). Furthermore, Ivana’s Putne bilješke (Travel Notes) point to the second stage in the historical development of tourism in Croatia. This period takes place at the end of the $19^{\text {th }}$ century, and is referred to as the stage of curiosity. Namely, tourism development

[2] Hotel Kronprinzessin Stephanie, today Imperial. 
was then stimulated by curiosity, and the first catering facilities were locally owned. Moreover, sail and steam shipping was developing, the first coastal rivieras (Opatija, Crikvenica, Dubrovnik) were being established. This was also the time of entry of foreign capital and construction of the railway network. The awareness of the benefits that tourism development brings was heightening. (Vukonić, 2005, 21) ${ }^{[3]}$

\section{1906. CRTICA OPATIJA: DIVOTE NJEGOVANE, JEDINSTVENE DOTJERANE OPATIJE (1906 SKETCH OPATIJA: NURTURED, UNIQUE, EMBELISHED SPLENDOURS OF OPATIJA)}

Ivana's second description of the contemporary Opatija dates back to 1906 when in the sketch Opatija (published in the collection Knjiga omladini (A Book for Youth) in 1923), she gives a very expressive picture of Opatija of that time. It is particularly interesting that this visit to Opatija was documented by a photograph of Ivana Brlić-Mažuranić, her husband Vatroslav and her son Ivan taken in the photographic studio of the court photographer Jelussich in Opatija (de Canziani 2016).

Ivana depicted Opatija at the beginning of the century in her sketch in four images. However, what is worth emphasizing strongly is that the author could now see certain changes in the landscape and lifestyle. This Opatija was also visited by a particular audience, often parvenus, but always wealthy people in the pursuit of luxury and frivolous pleasure. Therefore, resistance to all this mounted in the noble writer rich in spirit, and a slight smile of disdain emanates through the lines describing the fashionable summer resort. (Arambašin 2000, 170)

The third image of this prose, the third perception of Opatija, is now reflected in the spirit of the artist prompted by the noon bells, as an

[3] Because of the complexity of the tourism development and the various influences that left their mark on it, Vukonić decided to adopt the following historical framework of his analysis: the first stage - the period of the forerunners of tourism development or of phenomena similar tourism; the second stage - the end of the nineteenth century, or the curiosity stage; the third stage - the period from the beginning of the twentieth century to the end of the First World War or the "awareness-raising" stage; the fourth stage - the period between the two World Wars or the first stage of achievement; the fifth stage - after the Second World War or the stage of intense tourism development; the sixth stage from 1991 to the beginning of the twenty-first century, i.e. the stage of recovery and consolidation of tourist life in Croatia. This division represents the most important events that have had an impact on Croatia and its tourism and on the unfolding of social, cultural, political and economic events. (Vukonić 2005: 23-24) 
image of this landscape in its original appearance. (Arambašin 2000, 171)

O najednom, nastaje u meni slika: kako je ovdje bilo prije mnogo, Bog te pita koliko godina. Al je ovud vladala tišina. Sunce, spokojno i zlatno, oblijevalo je svu onu krš. More je ostajalo tiho, samo se dvostruka brazda širila za brodicama, koje su vozila trešnje tamo preko Kvarnera. (...) Po dražicama desno, lijevo, posvuda, kupali se „mići“ - samo oni! (...) Učka, sva u suncu, miruje svečanim mirom(...).

All of a sudden, an image grows in me: what it was like here many, God knows how many years ago. How silence reigned here. The sun, serene and golden, pervaded all that karst. The sea remained silent, only a double wake spread behind the boats, which transported cherries over the Kvarner. (...) In the coves to the right, to the left, everywhere, little children swam - just them! (...) Učka, in the sun, rests in solemn peace (...).

And in this reverie the author asks:

Sad: tko zna je li baš tako bilo? No, meni se tako prikazalo i neiskazana ljubav obuzela me za tu drevnu našu krasotu. (BrlićMažuranić 2007, 36)

Now: who knows if it was really so? But, this is how it was shown to me and an untold love for this ancient beauty of ours overwhelmed me. (Brlić-Mažuranić 2007, 36)

The fourth, last image follows. We are back into reality:

Opet čujem: udara glazba, trube automobili, gosti i gošće cijuču u kupalištu i vuku se morem uz mrežu na bojadisanim stupovima. (...) (Brlić-Mažuranić 2007, 37)

I can hear it again: music strikes, car horns blare, guests chirp in the bathing pool and move very slowly through the sea along the nets on the coloured poles. (...) (Brlić-Mažuranić 2007, 37)

It is evident that in the second - literary description - of Opatija, dating from 1906, Ivana, with a somewhat critical spirit of an adult 
lady from the upper spheres of society, nevertheless misses the onetime genuine rustic arcadian Opatija (de Canziani 2016). This twofold Ivana's image of Opatija revealing the relentless incursion of new tendencies of development, which are somewhat in disagreement with the "good old days" of intact virgin indigenous life in this area, testifies to the third stage of historical development of tourism in Croatia. It is a period from the beginning of the $20^{\text {th }}$ century to the end of the First World War; this stage is also called the stage of awareness-raising. At this stage, the affirmation of tourist-health centres in the Adriatic (for example, Opatija, Crikvenica, Hvar) takes place, while some places define their development as a vision of tourism development (Vukonić 2005, 22).

\section{1913. LOVRAN: SVE NAJMODERNIJE I U VELIKOM STILU (1913 LOVRAN EVERYTHING IS THE MOST MODERN AND IN GREAT STYLE)}

In May 1913, Ivana Brlić-Mažuranić resided with her husband Vatroslav and their eldest daughter Nada in Lovran. Lovran, along with Opatija, is the largest tourist resort in Liburnia. While Opatija evolved as a very dynamic fashionable centre, Lovran maintained the reputation of a sophisticated and somewhat isolated health resort whose peace provided a haven for many of the prominent figures of the uppermost Vienna and Budapest societies, as well as other parts of Europe. Ivana and her family came to this and such Lovran in May 1913.

Nevertheless, she also visited Opatija. This is evidenced by two letters written by Ivana to her mother (Henrietta, née Bernath) and a postcard sent to Ivana's daughter Zori and a postal card sent to her daughter Zdenka. The letters are kept in the Archives of the Brlić Family (Box No. 70, Vol. 16). They are presented here in clean copy, with some illegible parts.

This is the first presentation of these documents to the expert public in the English language. The first letter is dated $13^{\text {th }}$ May 1913. Ivana points out that they are very comfortable in Lovran:

Sobe imamo jednu uz drugu, u vrtu tik nad morem... Spavamo do 8 ili $1 / 29$ - izlazimo istom oko $1 / 211$ - jedemo toliko da me je 
sram, idemo svaki dan na kakav izlet, a pjevamo i smijemo se u naše dvije sobe...

The rooms are next to each other, in the garden just over the sea ... We sleep in until 8 or 8.30 - we go out as late as about 10:30 - we eat so much that I am ashamed, we make an excursion every day and we sing and laugh in our two rooms...

and mentions Villa Splendid:

„Villa Splendid“ novi pension, malo izvan Lovrane ( naime 5 minuta hoda) (...) pred kućom ( to je velika prednost jer po vrućini ići /.../). - Ciene vrlo umjerene. Lift u kući. Sve najmodernije i u velikom stilu.

"Villa Splendid", a new boarding house, just outside of Lovran (5 minutes' walking distance) (...) in front of the house (this is a great advantage because walking in this heat /.../). - Prices are very moderate. There is a lift in the house. Everything is the most modern and in great style.

Villa Splendid is today's tourist (unfortunately, neglected and devastated) Splendid Complex, which consists of three buildings: the Splendid Hotel, the Fani Villas and the hotel annex. It is the southernmost part of Lovran, towards Medveja and above the Peharova Bay. Ivana indicates the importance of the bathing site. Namely, in the Peharova Bay, in the southern part of Lovran, there was a wooden bathing area open to the public on $1^{\text {st }}$ June 1908 . This facility followed the line of the cove line in a slight angle curve, it was located on the beach mostly covering it. The ground floor was made of masonry, the cabin door openings were rectangular. The superstructure was wooden, the first floor was shaped in a series of cabins with a patio and columns connected by a fence with cross-lined slats in a rectangular field. (Kos 2010, 192).

In this letter Ivana reports that they visited Opatija:

i tu smo pred café Quarnero sproveli popodne.

and here, in front of the Quarnaro Café ${ }^{[4]}$, we spent our afternoon.

[4] In Opatija between 1884 and 1885, two representative hotel buildings were built, today known as Kvarner and 
She also recommends Opatija to her mother for her vacation:

Ja ću se još na jednom mjestu razpitati u Opatiji - Slatini gdje je takodjer kupelj pred nosom, a vrlo živahan promet i široki vidik na more. Samo će tu nešto skuplje biti. Ali napokon razlika može na dan dvie tri krune biti.

I will ask about in another place in Opatija - Slatina ${ }^{[5]}$ where the bathing place is also under your nose, with very lively traffic and a wide view of the sea. Only, it will be somewhat more expensive here. But the difference can be two to three crowns a day.

She continues to describe the villa where they stayed in Lovran:

Naša villa je takodjer upravo divna za ljeto i ja, koliko sam vidila u Opatiji-Lovrani, neznam za nijednu villu koja bi toliko hlada dala u ljeto a kupelj morska ravno iz vrta deset skalina pak si u svom privatnom kupalištu. Ali ta je villa tako u svom vrtu dolje sakrita i zakrivena, da ne vidiš od kopnenog svieta ništa. A cieli ton ville je bürgerlich.

Our villa is simply wonderful for the summer and, from what I have seen in Opatija-Lovran, I do not know of any other villa that would have so much shade in the summer and a sea bathing site straight from the garden, ten steps down and you are in your private bathing area. But this villa is so hidden and sheltered in its own garden below that you cannot see anything of the inland life. And the entire tone of the villa is bürgerlich.

From Ivana's description, it is not possible to accurately define which villa in Lovran this could be. It could be the southern part of Lovran, since Ivana mentions the villa Splendid. Namely, in that part of Lovran there are a number of villas with remarkable architectural and decorative elements. First of all, irrespective of the area of Lovran where the villa could be located, Ivana indicates that it is the seaside or eastern side. Namely, Lovran is crossed by the main road in the north-south direction

Imperial. Ivana mentions the Quarnero Café - today's Hotel Kvarner, while and in the first encounter with Opatija in 1889 she mentions "Hotel Štefanija", that is, the hotel Kronprinzessin Stephanie (today's Imperial).

[5] Slatina je najpoznatije opatijsko kupalište i danas. Nalazi se u samom središtu, uz obalnu šetnicu Lungomare, i glavnu prometnicu. 
and stretches along the sea, with villas stringing on the west inland side above the road, and on the east side, below the road, on the seashore.

If we assume that Ivana spent her summer in the southern part of Lovran, the starting point should be from the pier - "mul", which will be further discussed in this paper, towards the southernmost point of the Peharova Bay. It is a series of buildings with direct access to the beach and the sea from their gardens down their own stairs.

It is, however, possible that Ivana stayed in a villa in the central part of Lovran. In the second letter, she mentions going to visit friends in the villa Iris, which is located right in the central part.

Ivana wrote the second letter to her mother on $16^{\text {th }}$ May 1913. This letter describes the departure for a solemn dinner in the mentioned villa. Villa Iris is a building that was later renamed the Miramar Hotel. Built in 1895 , it is a large two-storey building, conceived as a Renaissance villa of the Tuscan type with its pronounced and raised lateral wings. The building was considerably extended to the south in 1904. (Peršić 2002, 113-114)

In general, in her descriptions of her stay in Lovran, Ivana expressed a mature and prudent decision in choosing her vacation destination. She was aware of the meaning of rest and detachment as parts of the refined life of the then Central European upper middle class.

Here is a quote from the letter:

Naš se boravak primiče kraju - ali nam je žao još ustanoviti konačni dan odlazka. Mi nalazimo da nam je samo zato tako liepo što smo podpuno bez plana živili pak tako kanimo i naš odlazak u zadnji čas odrediti.

Our stay is coming to an end - but we still do not want to determine the day of departure. We find that we are having such a beautiful time because we lived without any plan and that is how we are going to determine our departure at the last minute.

This is also evidenced by a postcard and a postal card she sent.

\section{1913. Postcard: Lovrana - Molo bei Scirocco}

Ivana Brlić-Mažuranić also sent a postcard during her stay in 
Lovran in 1913. It was sent to Ivana's daughter Zora Brlić on $13^{\text {th }}$ May 1913. However, it was sent from the villa of the Potočnjak family in Novi (hence the postmark Novi). On the front is the picture of Lovran with/bearing the title: Lovrana - Molo bei Scirocco (the Lovran "mul" /pier/ battered by high waves caused by the scirocco - a south wind). It is the part where the southern part of Lovran commences. The postcard was printed by Verlag: Philipp Rubel, Wien IX.

\section{1913. POSTAL CARD: LIEPO NAM JE OVDJE (WE ARE HAVING A BEAUTIFUL TIME HERE)}

Ivana also sent a postal card from Lovran to her daughter Zdenka in Zagreb. The postmark reads: Lovran, 15. 5. 1913. Lovran, 15.V. On the back, Ivana wrote:

Draga Zdenka!

Liepo nam je ovdje i već smo pohrvatili sve ono što je još talijansko bilo - premda je u tomu veliki napredak odkad ovdje nismo bili. Samo oni mići (mali) koji idu u talijansku školu znadu još talijanski. Vrieme je prekrasno.

Mama

Dear Zdenka!

We are having a beautiful time here and we have already croatised everything that was still Italian - although there has been a great progress since we were here. Only the little children who go to the Italian school still know Italian. Weather is beautiful.

Mama

On the front of the postcard is a painting from the Russian Museum of Emperor Alexander III. The painter is I.Y. Repin and the image is his famous painting Reply of the Zaporozhian Cossacks to Sultan Mehmed IV of the Ottoman Empire.

On the back of the postal card, it is apparent that the stationery is from Russia, the information is also written in Cyrillic: GRANBERGS BREFKORT - РОЧТОВАЯ КАРТОЧКА. So is the information on the front of the postcard: Русскій Музей Императора Александра III. И. Е. 
РЂПИНЪ. Запорожцы сочиняющіе пісьмо Туреџкому султану. And in French: Musée russe de l'Empereur Alexandre III. I. E. RIEPIN. Les cosaques écrivant une lettre au sultan turc ${ }^{[6]}$. We wonder whether Ivana's choice of the scene on the postal card is just a coincidence, or if it testifies, in addition to Ivana's sense of vivacious humour and justice where good triumphs over evil, little over great, joyfully over sadness, above all of her love of the Croatian homeland as the basis of the feelings of the Slavic spirit and slavophilia.

\section{CONCLUSION}

After analysing the recently discovered documents from the correspondence of Ivana Brlić-Mažuranić, as well as her memoirs and literary records about her first meeting with the sea and her arrival to Liburnia, but also her later visits, certain conclusions can be drawn. On the one hand, we have presented the age and area to which Ivana comes - Liburnia in late $19^{\text {th }}$ and early $20^{\text {th }}$ centuries. In a series of distinguished persons, especially writers, who visited this magical coastal region, there is no mention of the distinguished Croatian writer and the first academician of the Yugoslav Academy of Sciences and Arts. To this end, hopefully, this work has highlighted the importance and the fundamental achievements of this part of Ivana's life and creation. On the other hand, we believe, along with Mato Artuković, Ph.D. (2016, 450), that the inhabitants of Opatija (and of the entire Liburnia, we would add) will be happy to quote Ivana's observations about their town and their homeland. In the linguistic sense, the observed material confirms that Ivana is a writer sensitive to the language (Arambašin 2000, 171). She thus perceives the linguistic peculiarities of the speech of the region in which she is staying. First of all, those of the Chakavian. On the other hand, Ivana's language, styling, especially in its correspondence, reveals the complexity of linguistic expression, characteristic of the then Central European middle class. The discourse thus has many German words, phrases, whole sentences, then French, Russian and others. In the orthography, it is worth noting Ivana's

[6] In addition, Акц. О: во Ѓранберѓь въ Стокгольмъ. 4542. In the upper right margin on the back someone wrote: Запорожku Kozak Han(j)a? 
varied recording of the proper noun Opatija: Abbazia, Opatija, Abazzija, Abazzia. Lovran is consistently called Lovran. Furthermore, Ivana's fiery patriotism, love for her homeland, Croatia can be observed throughout the studied material.

In general, the observed material points to Ivana's deep and intimate encounters with Liburnia as a geographical area that provided her with abundant joy, rest and inspiration. 


\section{REFERENCES}

Arambašin, T. 2000. 'More u djelima Ivane Brlić-Mažuranić.' Nova Istra, 1-2: $168-180$.

Artuković, M. 2016. 'Pogovor priređivača. Dnevnički i memoarski zapisi Ivane Brlić-Mažuranić.' In Brlić-Mažuranić, Ivana: Moji zapisci. Dnevnici, memoari, molitve, putni i drugi zapisi. Artuković, Mato, prir.; Brešić, Vinko, ur., 441-475. Slavonski Brod: Ogranak Matice hrvatske Slavonski Brod.

Brlić-Mažuranić, I. 2016. 'Putne bilješke.' In Brlić-Mažuranić, Ivana: Moji zapisci. Dnevnici, memoari, molitve, putni i drugi zapisi. Artuković, Mato, prir.; Brešić, Vinko, ur., 23-39. Slavonski Brod: Ogranak Matice hrvatske Slavonski Brod.

De Canziani, T. 2016. 'Predavanje s projekcijama u povodu 100. obljetnice prvog izdanja Priče iz davnine’, utorak 10.svibnja 2016. u auditoriju Vile Antonio u Opatiji, ogranak Matice hrvatske u Opatiji. Kolo, http://www. matica.hr/ogranci/Lovran/zbivanja/1700/ (pristup 4. rujna 2018.)

Kos, M. 2010. 'Počeci izgradnje kupališnih mjesta s osvrtom na lovranska kupališta početkom 20. stoljeća’. In Zbornik Lovranšćine, ed. I. Eterović, 181-196. Lovran: Katedra Čakavskog sabora Lovran.

Muzur, A. 2004. Zlatna knjiga gostiju Opatije. Opatija: Turistička zajednica grada Opatije.

Peršić, M. 2002. Lovran - turizam i graditeljstvo. Turistička arhitektura u Lovranu na prijelazu iz 19. u 20. stoljeće. Rijeka: Adamić.

Vukonić, B. 2005. Povijest hrvatskog turizma. Zagreb: Prometej.

Zakošek, B. 2005. Opatijski album, Dugo stoljeće jednog svjetskog lječilišta. Rijeka: Državni arhiv u Rijeci. 


\section{SOURCES}

Brlić-Mažuranić, I. 1913. Dopisnica Zdenki Brlić, 15.V. 1913. AOB , kutija inv. br. 75 , sv. 4 .

Brlić-Mažuranić, I. 1913. Pismo majci Henrietti, 16. V. 1913. AOB, kutija inv. br. 70, sv. 16.

Brlić-Mažuranić, I. 1913. Razglednica Zori Brlić, 13.V.1913. AOB, kutija inv. br. 74, sv. 6 .

Brlić-Mažuranić, I. 2007. 'Opatija.' In Brlić-Mažuranić, I.: Knjiga omladini, 35-37. Zagreb: Večernji list. 


\section{APPENDICES}

1. Photograph: Opatija, 29.7.1906. Ivan Brlić, Dr.Vatroslav Brlić, Ivana Brlić Mažuranić. From the Mažuranić-Brlić-Ružić Memorial Library and Collection, under the suplemented title of the Matilda Ružić Foundation. Ivana's second description of the contemporary Opatija dates back to 1906 when in the sketch Opatija (published in the collection Knjiga omladini (A Book for Youth) in 1923), she gives a very expressive picture of Opatija of that time. It is particularly interesting that this visit to Opatija was documented by a photograph of Ivana Brlić-Mažuranić, her husband Vatroslav and her son Ivan taken in the photographic studio of the court photographer Jelussich in Opatija.

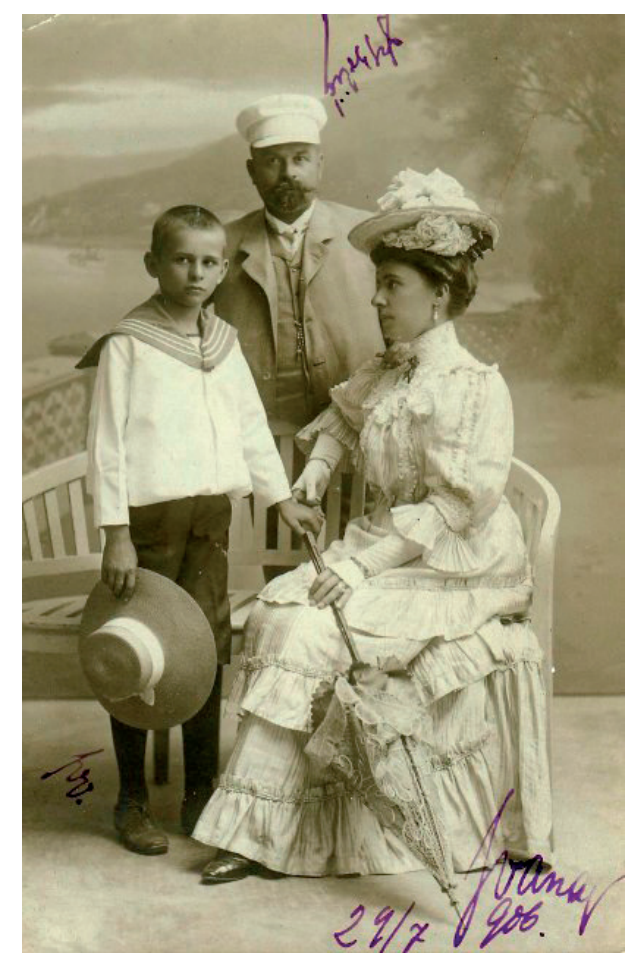

2. Postcard (front side): Lovrana - Molo bei Scirocco. $13^{\text {th }}$ May 1913 (addressed to Zora Brlić). In the Archives of the Brlić Family. On the front is the picture of Lovran with/bearing the title: Lovrana - Molo bei Scirocco 
(the Lovran "mul" / pier/ battered by high waves caused by the scirocco - a south wind). It is the part where the southern part of Lovran commences.

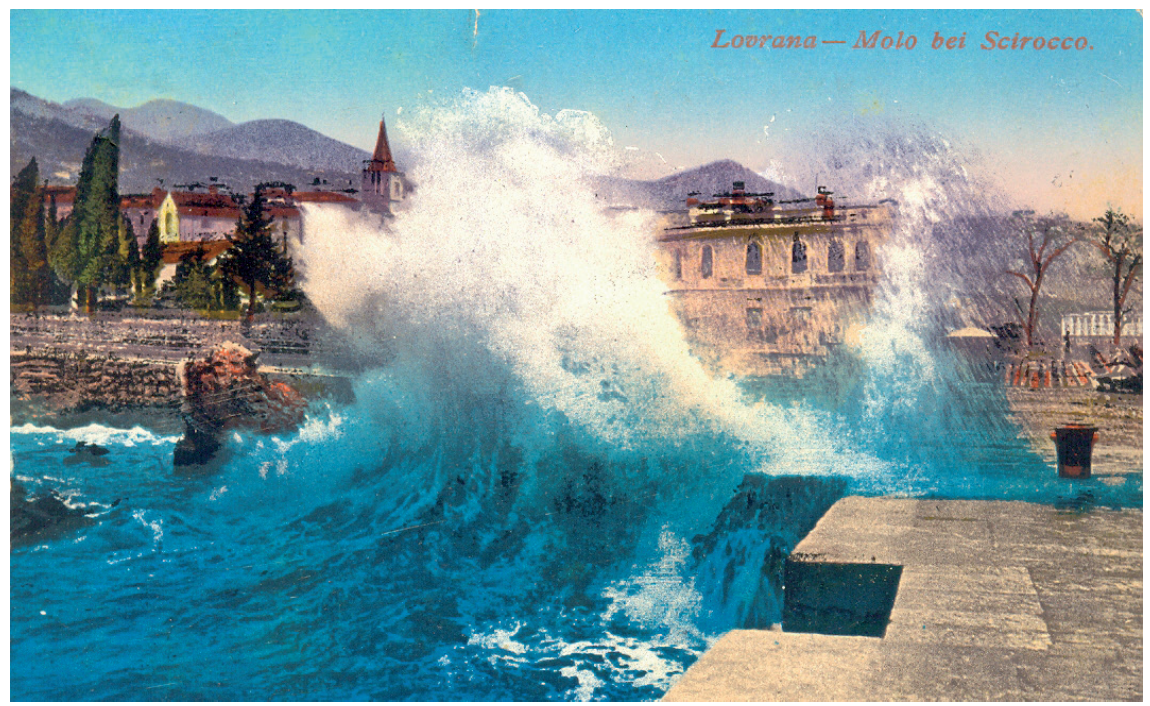

3. This is evidenced by two letters written by Ivana to her mother (Henrietta, née Bernath). This is the first presentation of these documents to the expert public in the English language. The first letter is dated $13^{\text {th }}$ May 1913. Ivana points out that they are very comfortable in Lovran: The rooms are next to each other, in the garden just over the sea ... We sleep in until 8 or 8.30 - we go out as late as about 10:30 - we eat so much that I am ashamed, we make an excursion every day and we sing and laugh in our two rooms ...) 


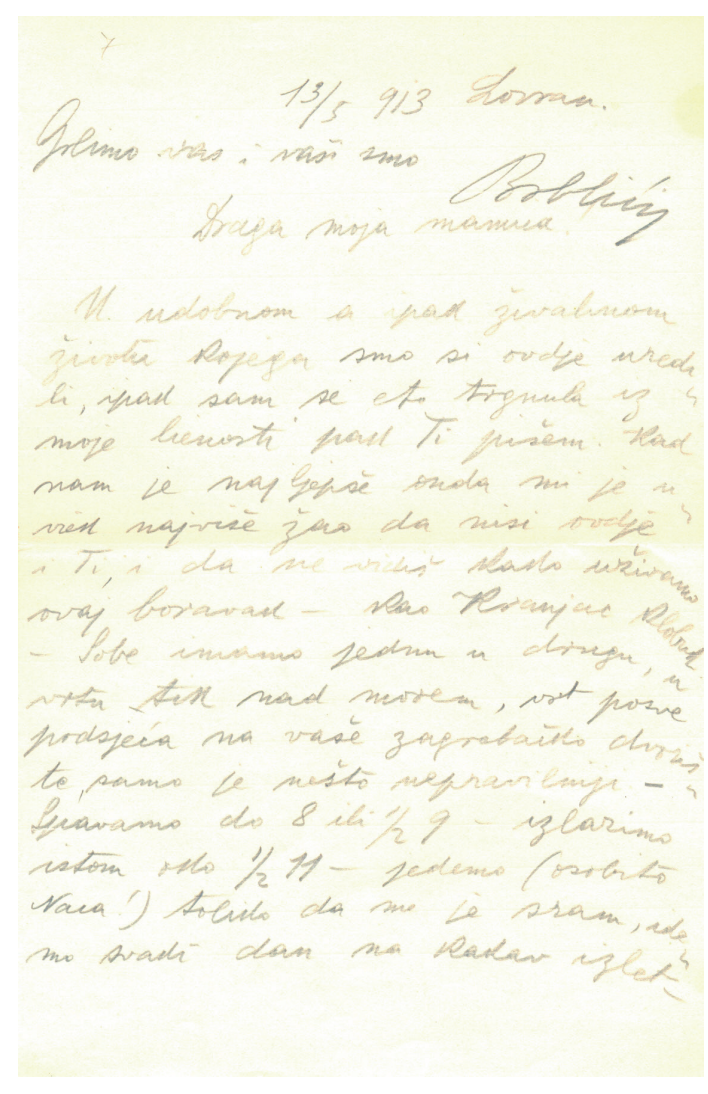

4. 1913. Postal Card: Ivana also sent a postal card from Lovran to her daughter Zdenka in Zagreb. The postmark reads: Lovran, 15. 5. 1913.

On the front of the postcard is a painting from the Russian Museum of Emperor Alexander III. The painter is I.Y. Repin and the image is his famous painting Reply of the Zaporozhian Cossacks to Sultan Mehmed IV of the Ottoman Empire. 


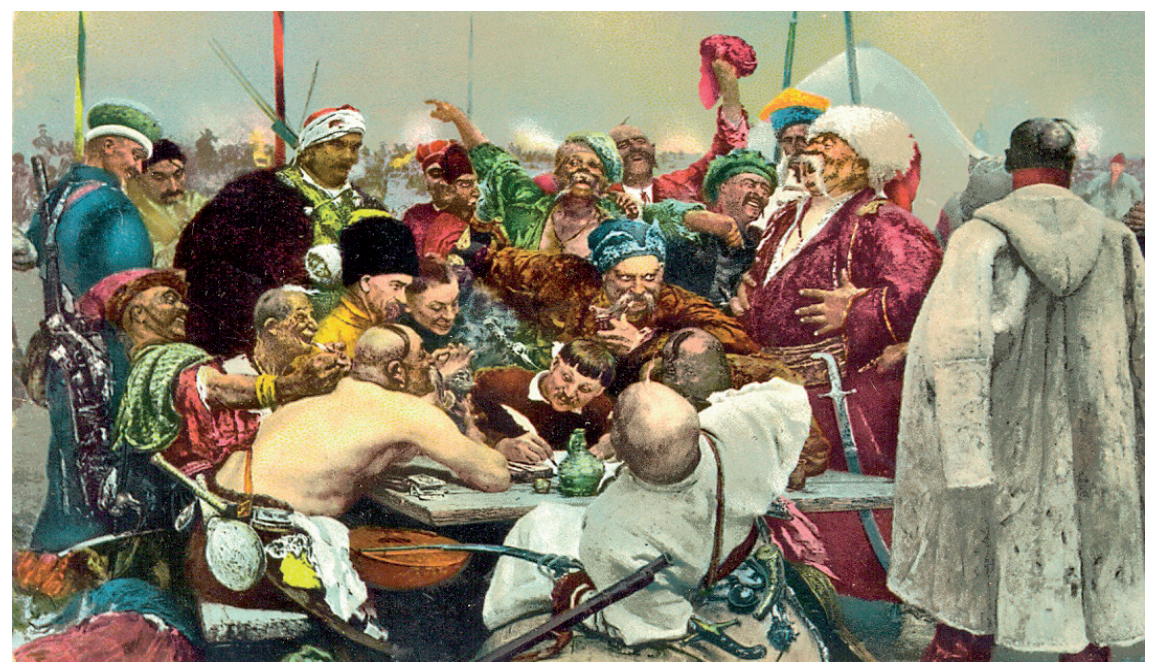

We wonder whether Ivana's choice of the scene on the postal card is just a coincidence, or if it testifies, in addition to Ivana's sense of vivacious humour and justice where good triumphs over evil, little over great, joyfully over sadness, above all of her love of the Croatian homeland as the basis of the feelings of the Slavic spirit and slavophilia. 